\title{
ОПТИМИЗАЦИЯ ПРОЦЕССА СУШКИ ЛЕКАРСТВЕННЫХ СРЕДСТВ, СОДЕРЖАЩИХ АЛКАЛОИДЫ С УЧЕТОМ ЭНЕРГО- И РЕСУРСОСБЕРЕЖЕНИЯ
}

\author{
А.Б. Голованчиков, А.А. Шурак, Н.А. Меренцов \\ Кафедра «Процессы и аппараты химических и пищевых производств», \\ ФГБОУ ВО «Волгоградский государственный технический университет», \\ 400005, Россия, Волгоград, пр. Ленина, 28.
}

DOI: 10.19163/MedChemRussia2021-2021-316

E-mail:a-shurak2@mail.ru

Затраты, связанные с эксплуатацией сушильных аппаратов, включают в себя стоимость электроэнергии, затрачиваемой на подачу сушильного агента, амортизационных отчислений на капитальные затраты и оборотных средств на эксплуатацию и ремонт. Обычно основную долю в суммарных затратах занимают вышеназванные энергозатраты.

Характер сушки зависит лекарственных средств, содержащих алкалоиды, из-за особенностей химического состава необходимо проводить при температурах, находящихся в пределах $40 \div 50{ }^{\circ} \mathrm{C}$, а иногда и при меньших значениях [1].

На примере сушки раунатина, оказывающим успокаивающим влиянием на центральную нервную систему, что немало важно для современного ритма жизни, перед стадией формовки, был проведен сравнительный расчет барабанной сушилки и сушилки с псевдоожиженным слое материала с учетом энерго- и ресурсосбережения [2]. Результаты расчетов, на производительность $G=100$ кг/час, при начальной и конечной влажности $w_{H}=0,9 \%$ и $w_{k}=0,15 \%$ и температуре горячего теплоносителя $t_{1}=45^{\circ} \mathrm{C}$, показали, что минимум затрат для барабанной сушилки составит $U_{\sigma}=14020$ руб/год, когда температура сушильного агента на выходе составила $t_{2}=25^{\circ} \mathrm{C}$, а для сушилки с псевдоожиженным слоем $U_{n}=10730$ руб/год и $t_{2}=20^{\circ} \mathrm{C}$ соответственно.

Из полученных данных видно, что барабанная сушилка менее экономична, нежели сушилка с псевдоожиженным слоем материала, на основании чего была разработана конструкция барабанной сушилки, позволяющая уменьшить минимум затрат и повысить энергоэффективность процесса сушки [3].

\section{Литература}

[1] Абрамчук А. В. Дикорастущие травянистые растения и их фармакологические свойства/ А. В.Абрамчук. - Екатеринбург, 2003. - 55 с.

[2] Свидетельство о гос. рег. программ для ЭВМ № 2020616467. Программа для расчета оптимальных технико-экономических параметров барабанной сушилки и сушилки с псевдоожиженным слоем высушиваемого материала/ А. Б. Голованчиков, Н. А. Прохоренко, Н. А. Меренцов, А. А. Шурак (РФ). Зарегистр. в реестре программ для ЭВМ. - 18 июня 2020.

[3] П. м. 202932 Российская Федерация, МПК F26B11/04. Барабанная сушилка / Голованчиков А. Б., Шурак А. А., Меренцов Н.А. и др.; ВолгГТУ. - 2021. 